\title{
Genes required for the synthesis of heptose- containing oligosaccharide outer core extensions in Haemophilus influenzae lipopolysaccharide
}

Correspondence

Derek W. Hood

derek.hood@ndm.ox.ac.uk

Received 8 June 2010

Revised 28 July 2010

Accepted 31 July 2010

\author{
Derek W. Hood, ${ }^{1}$ Mary E. Deadman, ${ }^{1}$ Mikael K. R. Engskog, ${ }^{2}$ \\ Varvara Vitiazeva, ${ }^{2}$ Katherine Makepeace, ${ }^{1}$ Elke K. H. Schweda ${ }^{2}$ \\ and Richard Moxon ${ }^{1}$
}

\author{
${ }^{1}$ Molecular Infectious Diseases Group, University of Oxford Department of Paediatrics, Weatherall \\ Institute of Molecular Medicine, John Radcliffe Hospital, Headington, Oxford OX3 9DS, UK \\ ${ }^{2}$ Clinical Research Centre, Karolinska Institutet and University College of South Stockholm, \\ Huddinge, Sweden
}

\section{INTRODUCTION}

Haemophilus influenzae is a common commensal of the upper respiratory tract of the human host but is also an important cause of disease. The majority of strains are unencapsulated (non-typable) H. influenzae (NTHi) that can by contiguous spread cause infection, such as otitis media (OM) and lower respiratory tract infections, particularly in infants. Occasionally, strains can be invasive, causing bacteraemic infections such as meningitis and septicaemia. Lipopolysaccharide (LPS) is the major glycolipid on the bacterial cell surface, is essential for $H$. influenzae and can have a role in both commensal behaviour and the pathogenesis of $H$. influenzae infections. $H$. influenzae LPS comprises a membrane-anchoring lipid A portion linked by a single 2-keto-3-deoxyoctulosonic acid (Kdo) molecule to a heterogeneous oligosaccharide (OS) composed mainly of neutral heptose (Hep) and hexose (Hex) sugars (Zamze \& Moxon, 1987). Each Hep of

Abbreviations: DD-Hep, D-glycero-D-manno-heptose; Hep, heptose; LCESI-MS $^{n}$, liquid chromatography-electrospray ionization-multiple step tandem MS; LD-Hep, L-glycero-D-manno-heptose; NTHi, non-typable $H$. influenzae; OM, otitis media; OS, oligosaccharide. a conserved trisaccharide inner core (HepI-HepIII) (Fig. 1a) can be a point for the addition of Hex sugars and further chain extension (Schweda et al., 2007, 2008). The degree and pattern of saccharide extension and the inclusion of phosphate- and non-phosphate-containing substituents all contribute to the structural heterogeneity of $H$. influenzae LPS. The expression of several epitopes of $H$. influenzae LPS is switched on and off at high frequency, socalled phase variation (Patrick et al., 1987; Weiser et al., 1989), a translational control mechanism involving microsatellites that is adaptive and advantageous for survival of bacteria confronted by the differing conditions, including the immune response, within the host.

Structural analyses of LPS have revealed that a fourth heptose (HepIV), either as a D-glycero-D-manno-heptose (DD-Hep) (Månsson et al., 2003a) or L-glycero-D-mannoheptose (LD-Hep) (Månsson et al., 2003b) enantiomer, can be included as part of the OS extension from HepI in a subset of NTHi strains (Fig. 1a). This HepIV residue can be substituted by further hexose extensions (Houliston et al., 2007; Månsson et al., 2003b), can be branched (Månsson et al., 2003a) or can be substituted by phosphocholine 


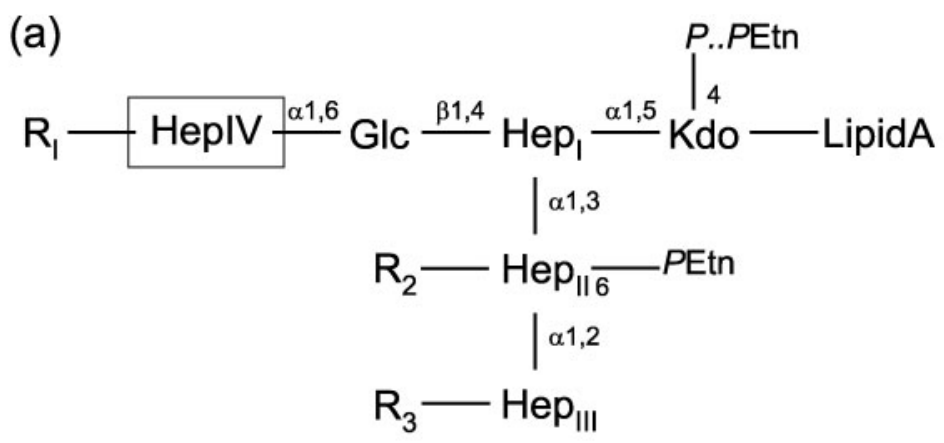

(b)
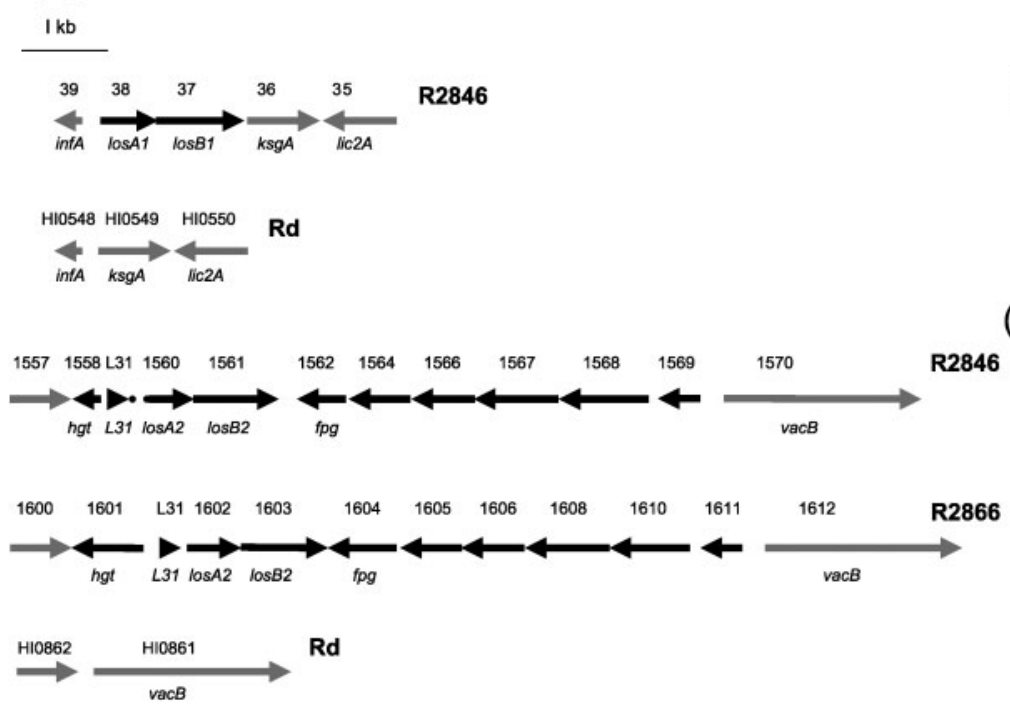

Fig. 1. Schematic representation of HepIV in the LPS of $H$. influenzae and the organization of the encoding genes. (a) The conserved tri-heptosecontaining inner core structure (Hepl-HepllI) with the location of HepIV indicated by a box. $R_{1}$, $R_{2}$ and $R_{3}$ represent addition of $H$ or sugar(s) dependent upon the strain. Hep, heptose; Glc, glucose; Kdo, 2-keto-3-deoxyoctulosonic acid; $P$ Etn, phosphoethanolamine; P..PEtn, pyrophosphoethanolamine. (b) Organization of the los genes determined from genome sequences. (i) The $\operatorname{los} A 1$ and $l o s B 1$ genes for strain R2846; (ii) the los $A 2$ and los $B 2$ genes for strains R2846 and R2866. The relative positions and orientations of the reading frames are represented by arrows drawn to scale, with the common gene names below and reading frame numbers derived from Artemis analysis of the complete $\mathrm{NCBI}$ genome sequence above. Flanking genes are represented by grey arrows. The corresponding chromosomal organization in strain $\mathrm{Rd}$ is shown for comparison in each case.
(PCho) (Fox et al., 2008). The gene repertoire required for the synthesis of the $H$. influenzae LPS molecule has been identified in a number of key strains (Hood et al., 1996a, 2001) following analyses based upon the whole-genome sequence of strain Rd (Fleischmann et al., 1995). However, the genes responsible for the incorporation of HepIV and its substitution were not identified by these methods, as these LPS epitopes, and presumably their genetic determinants, are not found in strain Rd. Following the completion of further genome sequences for NTHi strains (Erwin et al., 2005; Harrison et al., 2005), a candidate gene for a novel heptosyltransferase (los $B)$ was identified. $\operatorname{los} B$ is homologous to a gene characterized in the related species Haemophilus ducreyi (Tullius et al., 2002) that directs the incorporation of a fourth heptose in the LPS of this species (Post et al., 2007). The $\operatorname{los} B$ gene is found in a two-gene 'island' in a minority of $H$. influenzae strains (Erwin et al., 2005) alongside $\operatorname{los} A$, predicted to encode a phase-variable glycosyltransferase that can influence serum resistance of the bacteria (Erwin et al., 2006b). Structural analysis of LPS from an NTHi losB mutant strain has confirmed that $\operatorname{los} B$ encodes a heptosyltransferase (Lundström et al., 2008). We investigated the role of two homologous sets of $\operatorname{los} A$ and $\operatorname{los} B$ genes in the synthesis of heptose-containing OSs in the outer core of NTHi LPS.

\section{METHODS}

Bacterial strains and culture conditions. The $H$. influenzae parent strains used in this study are listed in Table 1 . Our 25 NTHi strains (Cody et al., 2003) and strain R2846 (Erwin et al., 2006b) are isolates from OM. NTHi strain R2866 is an isolate from invasive disease (Erwin et al., 2005) and NTHi strain 2019 is a clinical isolate that has been used in LPS structural studies (Phillips et al., 1992). H. influenzae strain RM118 (Rd; strain KW20) is a type d-derived laboratory strain lacking a capsule, and strain RM153 (Eagan) is a serotype $\mathrm{b}$ isolate from invasive disease (Anderson et al., 1972). Strains were grown at $37^{\circ} \mathrm{C}$ in brain heart infusion (BHI) broth supplemented with haemin $\left(10 \mu \mathrm{g} \mathrm{ml}^{-1}\right)$ and NAD $\left(2 \mu \mathrm{g} \mathrm{ml}^{-1}\right)$ or on BHI agar $(1 \% \mathrm{w} / \mathrm{v})$ supplemented with $10 \%(\mathrm{v} / \mathrm{v})$ Levinthal's reagent. For selection following transformation, kanamycin $(10 \mu \mathrm{g}$ $\left.\mathrm{ml}^{-1}\right)$, streptomycin $\left(50 \mu \mathrm{g} \mathrm{ml}^{-1}\right)$, erythromycin $\left(20 \mu \mathrm{g} \mathrm{ml}^{-1}\right)$ or tetracycline $\left(2 \mu \mathrm{g} \mathrm{ml}^{-1}\right)$ was added to the growth medium.

Escherichia coli strain DH5 $\alpha$, used for DNA cloning and plasmid propagation, was grown at $37^{\circ} \mathrm{C}$ in Luria-Bertani (LB) broth supplemented with ampicillin $\left(100 \mu \mathrm{g} \mathrm{ml}^{-1}\right)$, kanamycin $\left(50 \mu \mathrm{g} \mathrm{ml}^{-1}\right)$ or erythromycin $\left(300 \mu \mathrm{g} \mathrm{ml}^{-1}\right)$, as required (Sambrook et al., 1989).

PCR amplification and recombinant DNA methodology. Restriction endonucleases and DNA-modifying enzymes were obtained from Roche or New England Biolabs and used according to the suppliers' instructions. Plasmid DNA preparation was performed as described elsewhere (Sambrook et al., 1989). Chromosomal DNA was prepared from Haemophilus by the method described previously (Preston et al., 1996). 
Table 1. Results of PCR and LPS analyses of the fourth heptose of NTHi strains

\begin{tabular}{|c|c|c|c|}
\hline Strain & $\begin{array}{l}\text { HepIV } \\
\text { in LPS }\end{array}$ & $\begin{array}{c}\operatorname{los} A 1 / \operatorname{los} B 1 \\
\text { region }\end{array}$ & $\begin{array}{c}\operatorname{los} A 2 / \operatorname{los} B 2 \\
\text { region }\end{array}$ \\
\hline 162 & - & - & - \\
\hline 176 & DD-Hep & $\operatorname{los} A 1 / \operatorname{los} B 1$ & $\operatorname{los} A 2 / \operatorname{los} B 2 \dagger$ \\
\hline 285 & - & lic $2 B / l i c 2 C$ & - \\
\hline 375 & - & - & - \\
\hline 432 & - & $\operatorname{lic} 2 B / l i c 2 C$ & - \\
\hline 477 & DD-Hep & $\operatorname{los} A 1 / \operatorname{los} B 1$ & - \\
\hline 486 & - & $\operatorname{lic} 2 B / l i c 2 C$ & - \\
\hline 667 & - & lic2B/lic2CS & - \\
\hline 723 & - & - & - \\
\hline 981 & DD-Hep & $\operatorname{los} A 1 / \operatorname{los} B 1$ & - \\
\hline 1008 & - & lic $2 B / l i c 2 C$ & - \\
\hline 1124 & - & - & - \\
\hline 1158 & DD-Hep & lic $2 B / l i c 2 C$ & $\operatorname{los} A 2 / \operatorname{los} B 2 \dagger$ \\
\hline 1159 & DD-Hep & $\operatorname{lic} 2 B / l i c 2 C$ & $\operatorname{los} A 2 / \operatorname{los} B 2 \dagger$ \\
\hline 1180 & - & lic $2 B / l i c 2 C$ & - \\
\hline 1181 & - & $\operatorname{lic} 2 B / l i c 2 C$ & - \\
\hline 1200 & - & $\operatorname{lic} 2 B / l i c 2 C$ & - \\
\hline 1207 & LD-Hep & - & $\operatorname{los} A 2 / \operatorname{los} B 2 \ddagger$ \\
\hline 1209 & LD-Hep & - & $\operatorname{los} A 2 / \operatorname{los} B 2 \ddagger$ \\
\hline 1231 & DD-Hep & $\operatorname{los} A 1 / \operatorname{los} B 1$ & $\operatorname{los} A 2 / \operatorname{los} B 2 \dagger$ \\
\hline 1232 & DD-Hep & $\operatorname{los} A 1 / \operatorname{los} B 1$ & $\operatorname{los} A 2 / \operatorname{los} B 2 \dagger$ \\
\hline 1233 & LD-Hep & - & $\operatorname{los} A 2 / \operatorname{los} B 2 \neq$ \\
\hline 1247 & - & - & - \\
\hline 1268 & - & $\operatorname{lic} 2 B / l i c 2 C$ & - \\
\hline 1292 & - & $\operatorname{lic} 2 B / l i c 2 C$ & - \\
\hline $\mathrm{R} 2846$ & DD-Hep & $\operatorname{los} A 1 / \operatorname{los} B 1$ & $\operatorname{los} A 2 / \operatorname{los} B 2 \dagger$ \\
\hline $\mathrm{R} 2866$ & LD-Hep & - & $\operatorname{los} A 2 / \operatorname{los} B 2 \ddagger$ \\
\hline 2019 & - & lic $2 B / l i c 2 C$ & - \\
\hline Eagan & - & lic $2 B / l i c 2 C$ & - \\
\hline $\mathrm{Rd}$ & - & - & - \\
\hline
\end{tabular}

*Alternative gene arrangements are indicated.

$\dagger \ddagger$ Size of the hgtl gene produced with primer pair $2846 \mathrm{~A}$ and $2846 \mathrm{~F}$ ( $† 0.93 \mathrm{~kb}$, i.e. R2846-like; $\ddagger 1.53 \mathrm{~kb}$, i.e. R2866-like).

$\S \mathrm{PCR}$ product of a size smaller than that predicted for lic2B/lic2C due to the presence of a partial lic $2 B$ gene.

DNA fragments were amplified by PCR; conditions were $1 \mathrm{~min}$ periods of denaturation $\left(94{ }^{\circ} \mathrm{C}\right)$, annealing $\left(50{ }^{\circ} \mathrm{C}\right)$ and polymerization $\left(72{ }^{\circ} \mathrm{C}\right)$ for 30 cycles. To clone the los $A 1$ and losB1 genes, the region of DNA between the infA and $k s g A$ genes was amplified using primers infrev (5'-CCACGTGACCGTTTTCCAAC-3') and ksgArev (5'-GCATATCTTGAATCACATC-3') from genomic DNA isolated from strains R2846, 176 and 981. A $1 \mu$ volume of the PCR-amplified product of $2.47 \mathrm{kbp}$ was ligated with plasmid pT7Blue (Novagen) and transformed into E. coli. For R2846, the PCR product was initially cloned into the vector pCR2.1 (Invitrogen), then the insert, released on a BamHI-XhoI fragment, was subcloned into compatible BamHISall sites in pT7Blue. Recombinant plasmids were confirmed by restriction endonuclease digestion and PCR amplification, then the target genes were mutagenized by insertion of a kanamycin-resistance cassette $\left(\operatorname{kan}^{\mathrm{R}}\right)$ (from pUC4Kan, GE Healthcare) or a tetracyclineresistance cassette $\left(\operatorname{tet}^{\mathrm{R}}\right)$ [from pHVT1 (Danner \& Pifer, 1982)]. The losA1 gene was cut at a NsiI site, then ligated with a $\operatorname{kan}^{\mathrm{R}}$ released by digestion with PstI, whilst the losB1 gene was interrupted by ligating
$\operatorname{kan}^{\mathrm{R}}$, released with $A c c \mathrm{I}$, into a unique BstBI site within the reading frame. The $\operatorname{los} B 1$ gene was also digested at the same BstB1 site, endfilled using Klenow and dNTPs, then disrupted by inserting a tet ${ }^{R}$ released by digestion with HindIII, then end-filled with Klenow, to give plasmid p2846A3.1BstB1tet1.

The losA2 and losB2 genes were amplified using primers $2846 \mathrm{C}\left(5^{\prime}-\right.$ TGGTCGTGCAGAACGCTT-3') and 2846D (5'-AGTATGTGCGTTTCTGCC- $3^{\prime}$ ), and the neighbouring genes hgt 1 and L31 using primers 2846A (5'-TAAAAACATGGTGGGTGG-3') and 2846B (5'AAGAATAATAGCACGCGC-3' ${ }^{\prime}$ ) from strains R2846 and 176. Aliquots $(1 \mu \mathrm{l})$ of the PCR-amplified products of 1.75 and $1.31 \mathrm{~kb}$, respectively, were ligated with plasmid pT7Blue (Novagen) and transformed into E. coli. Recombinant plasmids containing the hgtl/ L31 and losA2/losB2 genes from NTHi strain R2846 and the losA2/ losB2 genes from NTHi 176 were confirmed by restriction endonuclease digestion and PCR amplification using the specific primers above, then were used to inactivate the target genes by insertional mutagenesis using a $\operatorname{kan}^{\mathrm{R}}$. Genes $h g t 1$ and $\operatorname{los} A 2$ were cut at $M f e$ I sites within the respective reading frame, then ligated with a $\operatorname{kan}^{\mathrm{R}}$ released by digestion with EcoRI, and $\operatorname{los} A 2$ was interrupted by ligating the same $\mathrm{kan}^{\mathrm{R}}$ into an EcoRI site within the reading frame. The gene losB2 was digested at a unique $\mathrm{NruI}$ site within the reading frame, end-filled using Klenow and dNTPs, and then disrupted by inserting $\mathrm{a} \mathrm{kan}^{\mathrm{R}}$ released by digestion with HincII.

The oligonucleotide primer pair infrev/ksgArev was used to screen for the presence of genes inserted between infA and $k s g A$ in each of the NTHi strains by PCR amplification. To determine whether these genes are lic $2 B$ and lic2C, primers specific for each gene (lic2BF $5^{\prime}$-GTCTTTCCGTTTCTAACTG-3'/lic2BB $5{ }^{\prime}$-AAGTATGATCCTCAAATG$3^{\prime}$ for $l i c 2 B$ and lic2BC 5'-CAATTTCACTAACTTGCC-3'/lic2BA 5'CATTTAGCGATGAGTTCC-3' for lic2C) were used. Correspondingly, to determine whether the $\operatorname{los} A 1$ and $\operatorname{los} B 1$ genes were present, the primer pairs R2846GTfor (5'-CAAGAAGAGCAATTATTTC-3')/ R2846GTrev (5'-GGTTCAATACCATAGGTG-3') and R2846hepfor (5'-GGTGTCATCTGCACCAAAC-3')/R2846heprev (5'-GATCTCATTAACATTATCG-3') were used, respectively.

Primer pairs losA2A ( $5^{\prime}$-GATATAATCGCTCAACGG-3')/losA2B (5' TCCAGTGAGTTGTAACGC-3') and losB2A (5'-GTTAAGGTTGGGTCTAGG-3')/losB2B (5'-TATGCGGATAATCGGCTG-3') were used to amplify specifically the $\operatorname{los} A 2$ and $\operatorname{los} B 2$ sequences, respectively, and primers 2846G (5'-GGCAGAAACGCACATACT-3')/ $2846 \mathrm{H}$ (5'-GGGCGACCTATACATTAG-3') the two genes downstream of losB2 from the NTHi strains. The oligonucleotide primer pairs $2846 \mathrm{~A} / 2846 \mathrm{~B}$ and $2846 \mathrm{C} / 2846 \mathrm{D}$ were used to screen for the presence of the hgt1/L31 and losA2/losB2 regions of DNA, respectively, in each of the $H$. influenzae strains.

Construction of mutant strains. A $1 \mu \mathrm{g}$ sample of recombinant plasmid containing an interrupted target gene was linearized by restriction digestion, then used to transform $H$. influenzae strains by the M-IV medium method (Herriott et al., 1970). All transformants were recultured on $\mathrm{BHI} /$ kanamycin or $\mathrm{BHI} /$ tetracycline, then confirmed as mutants by PCR amplification using the oligonucleotide primers described above and when appropriate by DNA sequencing.

Complementation of IosB1. Plasmid pEJ18 contains both an E. coli and an $H$. influenzae origin of replication plus an erythromycinresistance gene (E. Robinson, unpublished results). The cloned losA1losB1 region from R2846 was released from our recombinant plasmid by digestion with BamHI and XhoI, then ligated into pEJ18 digested with $\mathrm{NruI}$ and $\mathrm{XhoI}$. An in-frame deletion of the losAl gene was generated by digestion with DraIII, blunting of the ends and

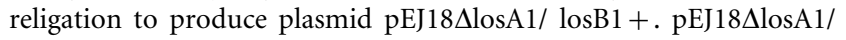

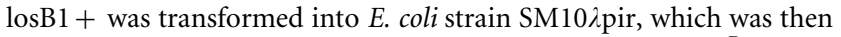
used as donor in conjugation with strain R2846losA1strep ${ }^{\mathrm{R}}$ (strain 
R2846losA1 transformed to streptomycin resistance using chromosomal DNA from RM154, a spontaneously resistant derivative of strain Eagan). Transconjugants were selected for on BHI plates containing streptomycin to select against the E. coli donor strain and erythromycin to select for the recipient $H$. influenzae harbouring the plasmid.

Analysis of LPS by electrophoresis. The patterns of LPS isolated from strains upon Tricine-SDS-PAGE (T-SDS-PAGE) were analysed as described previously (Hood et al., 1996a).

Serum resistance assay. A sample of $5 \times 10^{2}$ bacteria cultured on plates was assayed for survival against the killing effect of normal human serum as described previously (Hood et al., 1999). Experiments were carried out in triplicate.

Structural analysis of purified LPS. LPS purified from bacteria (Hood et al., 1996b) was subject to structural elucidation following procedures described previously (Lundström et al., 2008). Briefly, sugars were identified as their alditol acetates using authentic standards. Core OS fractions of R2486losA1 and R2486losA2 were obtained following mild acid hydrolysis of LPS and subsequent gel filtration chromatography. For $176 \operatorname{los} B 1$ and $176 \operatorname{los} B 2$, we applied a micro-method involving mild acid hydrolysis of $O$-deacylated LPS, reduction and dephosphorylation of resulting OS material in one reaction vial prior to permethylation as outlined previously (Gulin et al., 2003). Dephosphorylation was obtained after treatment with $48 \%$ hydrogen fluoride. Methylation analysis was accomplished on dephosphorylated OS using methyl iodide in DMSO in the presence of lithium methylsulfinylmethanide. Liquid chromatography-electrospray ionization-multiple step tandem MS (LC-ESI-MS ${ }^{\mathrm{n}}$ ) experiments on permethylated OS samples were performed in the positive ion-mode $[\mathrm{M}+\mathrm{Na}]^{+}$on a Finnigan LCQ ion trap mass spectrometer coupled to a Waters HPLC system.

\section{RESULTS}

\section{Genes required for biosynthesis of heptose- containing OSs}

OS extensions present in NTHi LPS can contain a fourth heptose, as either DD-Hep or LD-Hep, that can be further substituted, or branched, and thus the genetics underlying their biosynthesis is likely complex. In our search to identify genes required for the biosynthesis of heptosecontaining OSs, we investigated two chromosomal loci found in the genome sequences of NTHi strains. One of these loci contains two genes reported in $H$. influenzae, $\operatorname{los} A 1$ and $\operatorname{los} B 1$ (formerly called $\operatorname{los} A$ and $\operatorname{los} B$ ), that are homologues of LPS biosynthesis genes in the related species H. ducreyi (Erwin et al., 2005). In H. ducreyi these genes, known as $\lg b A$ and $\lg b B$, encode a galactosyltransferase and D-glycero-D-manno-heptosyltransferase, respectively (Post et al., 2007; Tullius et al., 2002). losA1 and losB1 are located between the infA and the $k s g A$ genes, and if present are in a position in the $H$. influenzae genome equivalent to that of the LPS genes lic2C and lic2B (Erwin et al., 2005; High et al., 1996; Hood et al., 2004a) (Fig. 1b), but share no homology to them. Thus, the infA/ksgA region represents a particular site of genetic diversity between strains (Erwin et al., 2005). The losA1 (AAY56464.1) and losB1 (AAY56463.1) genes are present in the genome sequence of NTHi strain R2846
(Erwin et al., 2005), but are not found in either NTHi strain R2866 or strain $86-028 \mathrm{NP}$. At a second distant chromosomal locus, further related genes, $\operatorname{los} A 2$ and $\operatorname{los} B 2$, were identified by homology searches in the genomes of strains R2846 and R2866, but not 86-028NP. The losA2 and losB2 genes in the R2846 genome sequence form part of a 10 -gene island of approximately $8 \mathrm{~kb}$ in length that comprises mainly genes inferred to play roles in iron metabolism (Fig. 1b). This group of genes is located in a position equivalent to that between genes HI0862 and HI0861 in the strain Rd genome sequence; in Rd there is only a 190 bp gap between these reading frames (Fig. 1b). For strain R2846, the losA1 and losA2 genes are $63 \%$ homologous and the transcribed products are $61 \%$ identical. Similarly, the $\operatorname{los} B 1$ and $\operatorname{los} B 2$ gene products are $68 \%$ similar and $58 \%$ identical to each other, albeit that Los $\mathrm{B} 1$ is predicted to be 14 aa shorter than LosB2. The $\operatorname{los} A$ and $\operatorname{los} B$ genes are contiguous at each of the two chromosomal sites (Fig. 1b); los $A 2$ and $\operatorname{los} B 2$ reading frames are separated by only $2 \mathrm{bp}$. In strain R2846, the $\operatorname{los} A 2$ reading frame is truncated, encoding a protein of only 44 aa, in contrast to the 225 aa protein encoded by $\operatorname{los} A 1$. Upstream of losA2 in strain R2846 is a frameshifted ribosomal protein gene (L31) and upstream of this is a gene encoding a further novel glycosyltransferase (ZP01784022), hgt1 (haemophilus glycosyltransferase 1), which has no significant homology to other $H$. influenzae genes. Five genes in this island downstream of losB2, and separated by the $f p g$ gene, are predicted to encode the components of an $A B C$ transport system (nhi1564-nhi1568 in Fig. 1b) involved in the transport of divalent cation-containing compounds, and nhi1569 has homology to genes encoding autotransporter adhesins. We would predict from the juxtaposition of many of these genes that their transcription would be co-dependent. The $f p g$ reading frame has high homology to part of mutM, a gene involved in DNA repair that is located at a separate chromosomal location (HI0964 in the Rd genome sequence). Each gene product from this island, with the exception of nhi1569, was almost identical in sequence to equivalent contiguous genes identified in Pasteurella multocida PM70 (1341 541-1 348996 bp on the genome sequence at http://cmr.jcvi.org).

In strain R2866, although the organization of the losA2/ losB2 region of DNA is overall similar (Fig. 1b), the hgt gene is $522 \mathrm{nt}$ longer than that in R2846 and the predicted gene product (ZP_00156727) shares homology with characterized glycosyltransferases $[43 \%$ identity with the galactosyltransferase Lic2A from $\mathrm{H}$. influenzae (High et al., 1996)]. Also in R2866, the losA2 gene encodes a predicted full-length and likely functional 222 aa protein of a length similar to the proteins produced in both $H$. ducreyi and $P$. multocida.

We investigated the distribution of the $\operatorname{los} A 1 / \operatorname{los} B 1$ and losA2/losB2 chromosomal loci by PCR amplification in our set of 25 NTHi strains, each expressing LPS that had been structurally characterized (Schweda et al., 2007), using combinations of internal and external primers specific for 
each locus. Between infA and $k s g A$, five strains contained losA1/losB1, 11 contained lic $2 B /$ lic $2 C$, eight had no genes present, and one contained a sequence smaller than predicted for $l i c 2 B / l i c 2 C$ due to the presence of a partial lic $2 B$ gene. The distribution of these alternative gene arrangements amongst strains was similar to that found for sets of throat-, OM- and invasive disease-related NTHi isolates (Erwin et al., 2005). For the second locus of interest, $\operatorname{los} A 2$ and $\operatorname{los} B 2$ genes were identified in eight of our 25 NTHi strains in a similar organization (Fig. 1b). Five of the eight NTHi strains contained the shorter hgt 1 sequence similar to that of strain R2846, and three NTHi strains had the longer R2866-like sequence (Table 1). By structural analysis, one or both of the $\operatorname{los} A 1 / \operatorname{los} B 1$ and los $A 2 / l o s B 2$ gene pairs were present in strains known to configure a fourth heptose, either an LD-Hep or a DD-Hep, in their LPS (Table 1). Only three of our 25 NTHi strains, 176, 1231 and 1232, contained both the $\operatorname{los} A 1 / \operatorname{los} B 1$ and losA2/losB2 gene sets, similar to strain R2846. Although each strain that included LD-Hep as HepIV in its LPS contained at least the $\operatorname{los} A 2 / \operatorname{los} B 2$ genes, no complete correlation between the presence of either gene set and the nature of HepIV could be made.

\section{Effect of mutation of IosA and IosB genes}

To investigate the roles of these two chromosomal loci in LPS synthesis, we mutated relevant genes in $H$. influenzae strains expressing a HepIV in their LPS. Mutants were obtained with either the los $A 1$ or $\operatorname{los} B 1$ genes knocked out in strain R2846 (DD-Hep) and 176 (DD-Hep) backgrounds, and the los $A 2$ or losB2 genes knocked out in the R2846, 176, 1207 (LD-Hep) and 1158 (DD-Hep) strain backgrounds. No NTHi strain mutated in the predicted glycosyltransferase gene, hgtl, was obtained. The LPS profile for each of these mutant strains was compared with that for the relevant parent strain. The LPS was truncated for the two strains R2846 (DD-Hep) and 176 (DDHep) mutated in the $\operatorname{los} B 1$ or $\operatorname{los} A 1$ gene (Fig. 2a). Some more minor changes in LPS profile were also observed for both $\operatorname{los} A 2$ and $\operatorname{los} B 2$ mutants, with the mutants in strain R2846 having LPS patterns skewed to the lower-molecularmass end of the range seen in the parent strain (Fig. 2a). LPS from the double mutant strain R2846losB1losB2 was truncated similarly to that isolated from the R2846losB1 single mutant strain. No difference in LPS profile, when compared with the wild-type, was found for either the los $A 2$ mutant or the losB2 mutant in strain 1158 (DD-Hep) (data not shown), and only some minor changes for mutants in strain 1207 (LD-Hep) (Fig. 2b). Although losB1 mutations in strains expressing DD-Hep as HepIV showed the biggest change in LPS profile compared with the wildtype, indicating that LosB1 would be the DD-heptosyltransferase, no complete correlation between LosB1 and LosB2 distribution and HepIV specificity in mutant strains was found.

For any given strain background tested, the LPS phenotypes of strains mutated in either the $\operatorname{los} A$ or the $\operatorname{los} B$ gene from the same locus were similar. This result strongly suggests co-dependent transcription of the $\operatorname{los} A$ and $\operatorname{los} B$ genes and a polar effect of mutation of $\operatorname{los} A$ on $\operatorname{los} B$ expression. We predict that LosA would add a hexose as part of any further extension from HepIV, with LosA1 predicted to add a glucose and LosA2 a galactose based on sequence similarities to other glycosyltransferases (Deadman et al., 2006, 2009). We cannot confirm losA function in the relevant mutant strain as the HepIVcontaining acceptor glycoform is absent. To establish the function of $\operatorname{los} A 1$, we constructed a derivative of strain $\mathrm{R} 2846 \operatorname{los} A 1$ in which $\operatorname{los} B 1$ function was complemented in trans on a plasmid. For this strain R2846 $\operatorname{los} \mathrm{l} 1 / \mathrm{B} 1+$, the molecular mass of LPS glycoforms observed was increased when compared with R2846losA1 (Fig. 2c).

HepIV-containing LPS glycoforms have previously been shown to include epitopes that influence serum resistance of NTHi strains (Erwin et al., 2006b; Houliston et al., 2007). For our strains, the killing effect of normal human

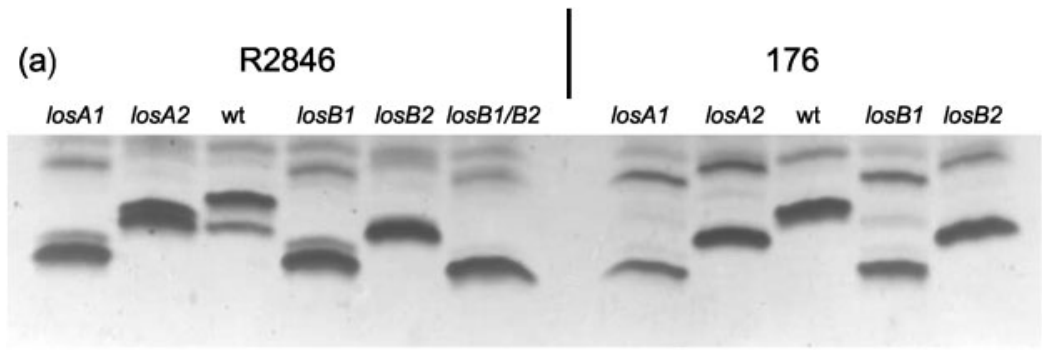

(b)

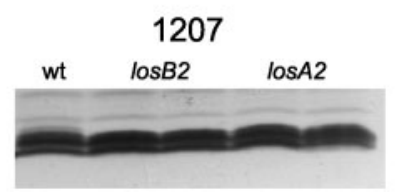

(c)

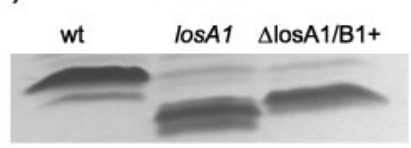

Fig. 2. Electrophoretic profiles of LPS isolated from strains mutated in LPS biosynthesis genes compared with the parent strain (wt). (a) $\operatorname{los} A$ and $\operatorname{los} B$ mutants for strains R2846 and 176; (b) los $A 2$ and losB2 mutants for strain 1207; (c) strain R2846, the los $A 1$ mutant and the complemented los $A 1$ strain $(\Delta \operatorname{los} \mathrm{A} 1 / \mathrm{B} 1+)$. 
serum was somewhat enhanced for each of the $\operatorname{los} A 1, \operatorname{los} B 1$, $\operatorname{los} A 2$ and $\operatorname{los} B 2$ mutants of both strain 176 (Fig. 3a) and strain R2846 (Fig. 3b) when compared with the respective parent strain. The double mutant R2846losB1/losB2 was one of the most serum-sensitive strains in this NTHi background (Fig. 3b). For NTHi strain R2866, there was little difference in serum resistance between the losA2 or losB2 mutant strain and the parent strain (data not shown).

\section{Structural confirmation of $\operatorname{los} A$ and $\operatorname{los} B$ function}

To properly interpret the changes in LPS phenotype observed with $\operatorname{los} A$ and $\operatorname{los} B$ mutant strains, the structure of LPS was determined for isogenic strains in the NTHi 176 and R2846 backgrounds. Sequence and branching details of the various glycoforms in core OS material were obtained using LC-ESI-MS ${ }^{\mathrm{n}}$ in the positive mode. Analyses of LPS from R2486losA1 indicated the total loss of DD-Hep (HepIV), virtually the same result obtained previously for strain R2486losB1 (Lundström et al., 2008) (Tables 2 and $3)$. For the complemented los 11 mutant, methylation analysis of LPS from R2846 $\Delta \mathrm{losA} 1 / \mathrm{B} 1+$ revealed major amounts of terminal DD-Hep, complete loss of 4-substituted DD-Hep, and a decrease of terminal Glc when compared with the wild-type strain (Table 2). This supports LosB1 function being restored in this $\operatorname{los} A 1$ mutant background. In the LC-ESI-MS ${ }^{\mathrm{n}}$ mass spectrum of dephosphorylated and permethylated OS from strain R2846 $\Delta \operatorname{los} A 1 / B 1+$ (positive mode, Fig. 4a), a major sodiated singly charged adduct ion $\left([\mathrm{M}+\mathrm{Na}]^{1+} ; \mathrm{m} / \mathrm{z}\right.$ 1716) was detected, corresponding to $\mathrm{Hex}_{2} \mathrm{Hep}_{4} A n \mathrm{Kdo}$-ol (Hex2Hep glycoform). By fragmenting this ion (Fig. 4a) we confirmed that HepIV is predominantly a terminal DDHep, in contrast to the wild-type strain, in which glucose is terminal (Lundström et al., 2008). For strain R2846losA2, compositional analyses of LPS indicated near identical ratios of sugars to those of strain $\mathrm{R} 2846 \Delta \operatorname{los} \mathrm{A} 1 / \mathrm{B} 1+$ (data not shown). In the LC-ESI-MS spectrum of dephosphorylated and permethylated OS from R2846losA2, major sodiated adduct ions $\left([\mathrm{M}+\mathrm{Na}]^{+}\right)$were observed at $\mathrm{m} / \mathrm{z}$ 1920 and 2124 (Fig. 4b), corresponding to Hex3Hep and Hex4Hep glycoforms, respectively (Table 3 ). In these latter glycoforms, HepIV is DD-Hep, which is further extended, since 4-substituted DD-Hep was detected in methylation analysis (Table 2). Thus, structural data for R2846losA2 LPS were similar to those from R2846losB2 and the wild-type strain (Lundström et al., 2008). These data are consistent with the hypothesis that $\operatorname{los} B 1$ encodes addition of the DDHep that is incorporated as HepIV exclusively in the wildtype strain, and that LosA1 functions as a glycosyltransferase, adding a glucose to this HepIV.

In a previous study, structural analysis of LPS from strain $\mathrm{R} 2846 \operatorname{los} B 1$ indicated that although DD-Hep was not expressed, minor quantities of LD-Hep were found in its place as HepIV (Lundström et al., 2008). LPS from R2486losB2 was very similar to that of the wild-type strain, and LPS from the R2846losB1/losB2 mutant showed no
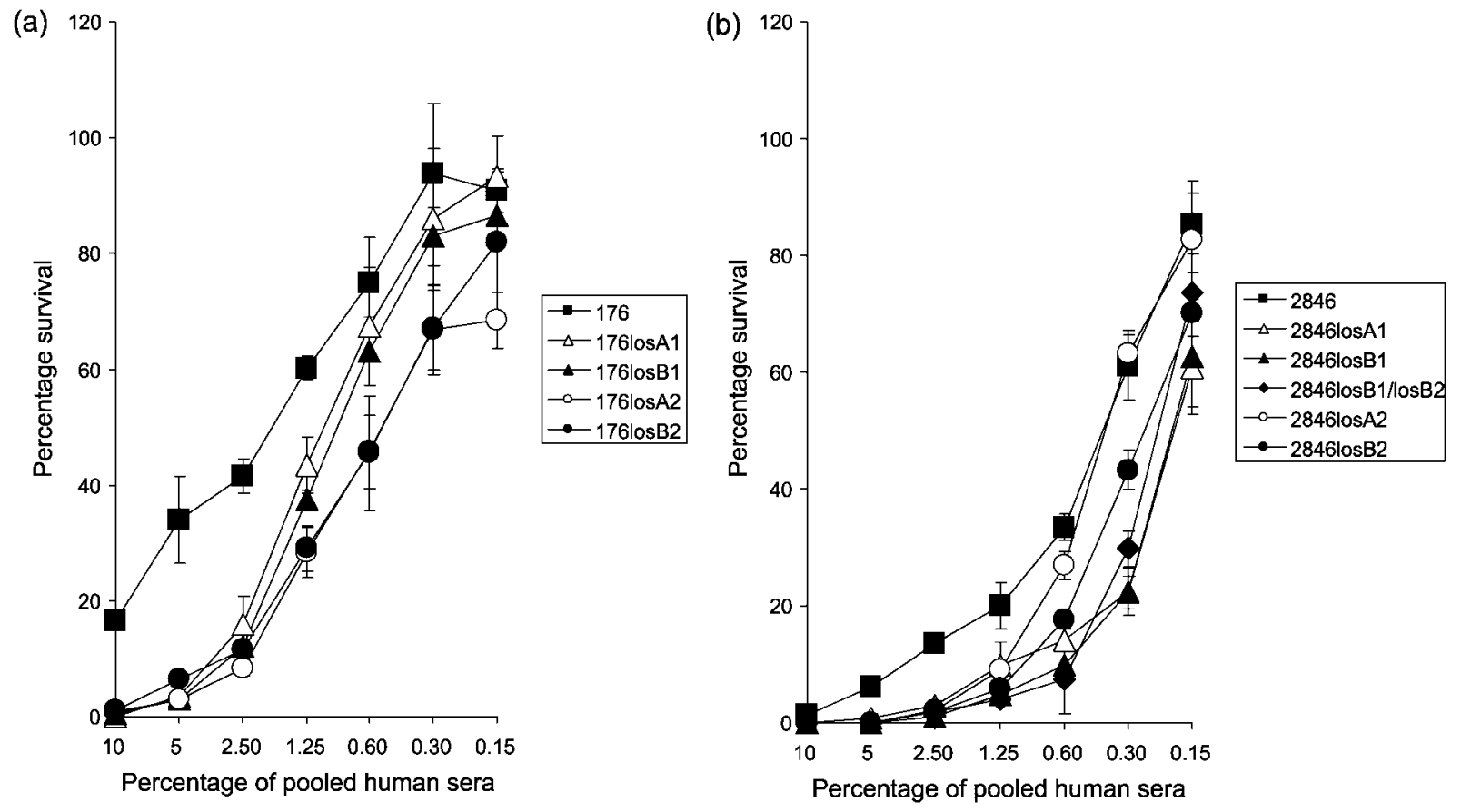

Fig. 3. Serum bactericidal assay of the relative killing of wild-type and mutant NTHi strains by normal human serum. The percentage survival of bacteria (relative to $t_{0}$ ) is plotted against doubling dilutions of human serum for NTHi strains 176 (a) and R2846 (b). The data shown are the mean from three repeat experiments; error bars, SD. 
Table 2. Methylation analysis of dephosphorylated OS samples derived from 176 and R2846 mutant strains

\begin{tabular}{|c|c|c|c|c|c|c|c|c|}
\hline \multirow[t]{2}{*}{ Methylated sugar* } & \multirow[t]{2}{*}{$t_{\mathrm{gm}} \dagger$} & \multirow[t]{2}{*}{ Linkage assignment } & \multicolumn{6}{|c|}{ Relative detector response (\%) } \\
\hline & & & $176 \operatorname{los} B 1$ & $176 \operatorname{los} B 2$ & $\mathrm{R} 2846 \operatorname{los} A 1$ & $\mathrm{R} 2846 \operatorname{los} A 2$ & $\mathrm{R} 2846 \Delta \operatorname{los} \mathrm{A} 1 / \mathrm{B} 1+$ & $\mathrm{R} 2846 \mathrm{wt} \ddagger$ \\
\hline $2,3,4,6-\mathrm{Me}_{4}-\mathrm{Gal}$ & 1.06 & D-Galp-(1- & 25 & 14 & 200 & 16 & 12 & 6 \\
\hline $2,3,6-\mathrm{Me}_{3}-\mathrm{Gal}$ & 1.22 & $-4)-\mathrm{D}-\mathrm{Gal} p-(1-$ & Trace & Trace & Trace & 1 & Trace & 2 \\
\hline $2,3,6-\mathrm{Me}_{3}-\mathrm{Glc}$ & 1.23 & $-4)-\mathrm{D}-\mathrm{Glc} p-(1-$ & 2 & 1 & 4 & 1 & Trace & 1 \\
\hline $2,3,4,6,7-\mathrm{Me}_{5}-\mathrm{Hep}$ & 1.32 & DD-Hepp-(1- & & & & & 14 & \\
\hline $2,3,4-\mathrm{Me}_{3}-\mathrm{Gal}$ & 1.36 & $-6)-\mathrm{D}-\mathrm{Gal} p-(1-$ & & & 2 & 1 & Trace & Trace \\
\hline $2,3,4,6,7-\mathrm{Me}_{5}-\mathrm{Hep}$ & 1.39 & LD-Hepp-(1- & Trace & & 5 & Trace & 2 & Trace \\
\hline 2,3-- $\mathrm{Me}_{2}-\mathrm{Glc}$ & 1.48 & $-4,6)-\mathrm{D}-\mathrm{Glc} p-(1-$ & & 2 & 1 & 4 & 4 & 3 \\
\hline 2,3,6,7-- $\mathrm{Me}_{4}$-Hep & 1.53 & -4)-DD-Hepp-(1- & & 18 & & 16 & & 17 \\
\hline 2,3,4,6- $\mathrm{Me}_{3}-\mathrm{GalN}$ & 1.75 & D-Gal $p$ NAc $p-(1-$ & & Trace & Trace & Trace & Trace & 2 \\
\hline 2,3,6- $\mathrm{Me}_{3}-\mathrm{GlcN}$ & 1.88 & $-4)-\mathrm{D}-\mathrm{GlcNAcp}-(1-$ & & Trace & Trace & Trace & Trace & 4 \\
\hline
\end{tabular}

*2,3,4,6- $\mathrm{Me}_{4}$-Glc represents 1,5-di-O-acetyl-2,3,4,6-tetra- $O$-methyl-D-glucitol- $1 \mathrm{~d}_{1}$, etc.

$\dagger$ Retention times $\left(t_{\mathrm{gm}}\right)$ are reported relative to $2,3,4,6-\mathrm{Me}_{4}$-Glc.

\$For comparison (from Lundström et al., 2008).

HepIV. To broaden these findings, we investigated a losB1 mutant of NTHi strain 176, which, as wild-type, expresses predominantly DD-Hep as HepIV (our unpublished results). Compositional analyses of LPS from strain 176 losB1 revealed no DD-Hep by GLC-MS analysis (data not shown). In the LC-ESI-MS spectrum of dephosphorylated and permethylated OS from 176losB1, the major sodiated adduct ion $\left([\mathrm{M}+\mathrm{Na}]^{+}\right)$was observed at $\mathrm{m} /$ $z$ 1468, corresponding to a Hex2 glycoform (Table 3). Minor ions at $m / z 1716,1920,2124$ and 2328 corresponded to Hex2Hep, Hex3Hep, Hex4Hep and Hex5Hep, respectively, indicating glycoforms that contain HepIV. Since LPS from $176 \operatorname{los} B 1$ did not contain DD-Hep, the fourth heptose was concluded to be a non-core LD-Hep. $\mathrm{MS}^{2}$ and $\mathrm{MS}^{3}$ experiments confirmed this heptose to be part of the outer core (Table 3). The 4,6-substituted LD-Hep observed in methylation analysis was concluded to be HepIV. Analyses of LPS from strain 176 losB2 gave virtually the same major glycoforms as the wild-type strain, with a major Hex3Hep glycoform in which HepIV is a 4-substituted DD-Hep (Table 2 ). In contrast to $176 \operatorname{los} B 1$, however, no traces of 4,6substituted Hep could be detected (Table 2), indicating that it did not express non-core LD-Hep. These data are consistent with LosB2 having an LD-heptosyltransferase function.

\section{DISCUSSION}

Genetic diversity across NTHi underlies the significant variation in surface structures within and between strains that facilitates adaptation in the human host. LPS structure can influence both the carriage of the bacterium and the likelihood of disease following NTHi infection (Erwin et al., 2006a; Schweda et al., 2007).

The two regions of the chromosome containing $\operatorname{los} A$ and $\operatorname{los} B$ genes investigated in our study are examples of NTHi genome diversity that contribute to the substantial heterogeneity of LPS structure that is observed between strains. In our set of $25 \mathrm{NTHi}$ strains, three alternative arrangements between infA and $k s g A$ are: no genes present (32\%), or the lic $2 B / l i c 2 C(48 \%)$ or losA1/losB1 $(20 \%)$ gene pair present. Association studies test links between the presence or absence of a particular DNA sequence in the genome and the ability of the relevant strains to cause disease (Erwin et al., 2005; Harrison et al., 2005). In an earlier study, either the losA1/losB1 or lic $2 B /$ lic $2 C$ genes were found in a majority of throat and OM NTHi isolates, but were absent in $40 \%$ of invasive isolates, although no definitive correlation with disease could be established for these genes (Erwin et al., 2005). In another study, lic2B had a skewed distribution amongst NTHi strains, being associated with one half of OM isolates but only $14 \%$ of strains isolated from the throat (Pettigrew et al., 2002).

The los $A 2$ and losB2 genes, present in $32 \%$ of our $25 \mathrm{NTHi}$ isolates, are part of a 10-gene island containing other genes with functions apparently directed mainly to divalent ion acquisition whose overall organization is conserved between strains. This island is located only three reading frames distant from the intergenic region (between HIO864 and HI0865 in the strain Rd genome sequence) where the 
Table 3. Glycoform composition elucidated by LC-ESI-MS ${ }^{n}$ (positive mode) of permethylated and dephosphorylated OS samples obtained from 176 and R2846 mutant strains

The glycoforms present and their relative abundance are indicated on the left of the table for each strain. All glycoforms contain Hep ${ }_{3} A n K d o-o l$. The right-hand side of the table details which glycose residues, denoted by the letters $\mathrm{k}, \mathrm{l}, \mathrm{m}, \mathrm{n}, \mathrm{o}, \mathrm{p}, \mathrm{q}, \mathrm{r}$ and $\mathrm{s}$ in the structure above the table, are present. Numbers greater than 1 indicate that multiple glycose residues of similar type are added to the same starting position. The relative isomer abundance for each glycoform is indicated on the extreme right of the table (A-E).

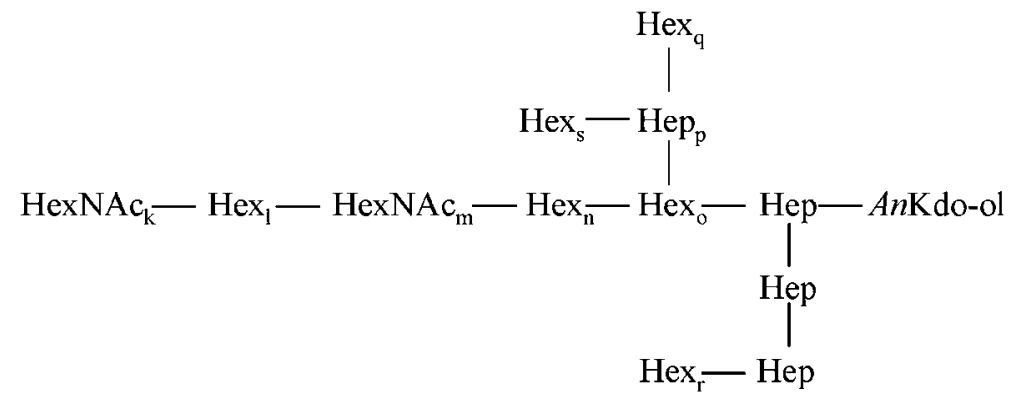

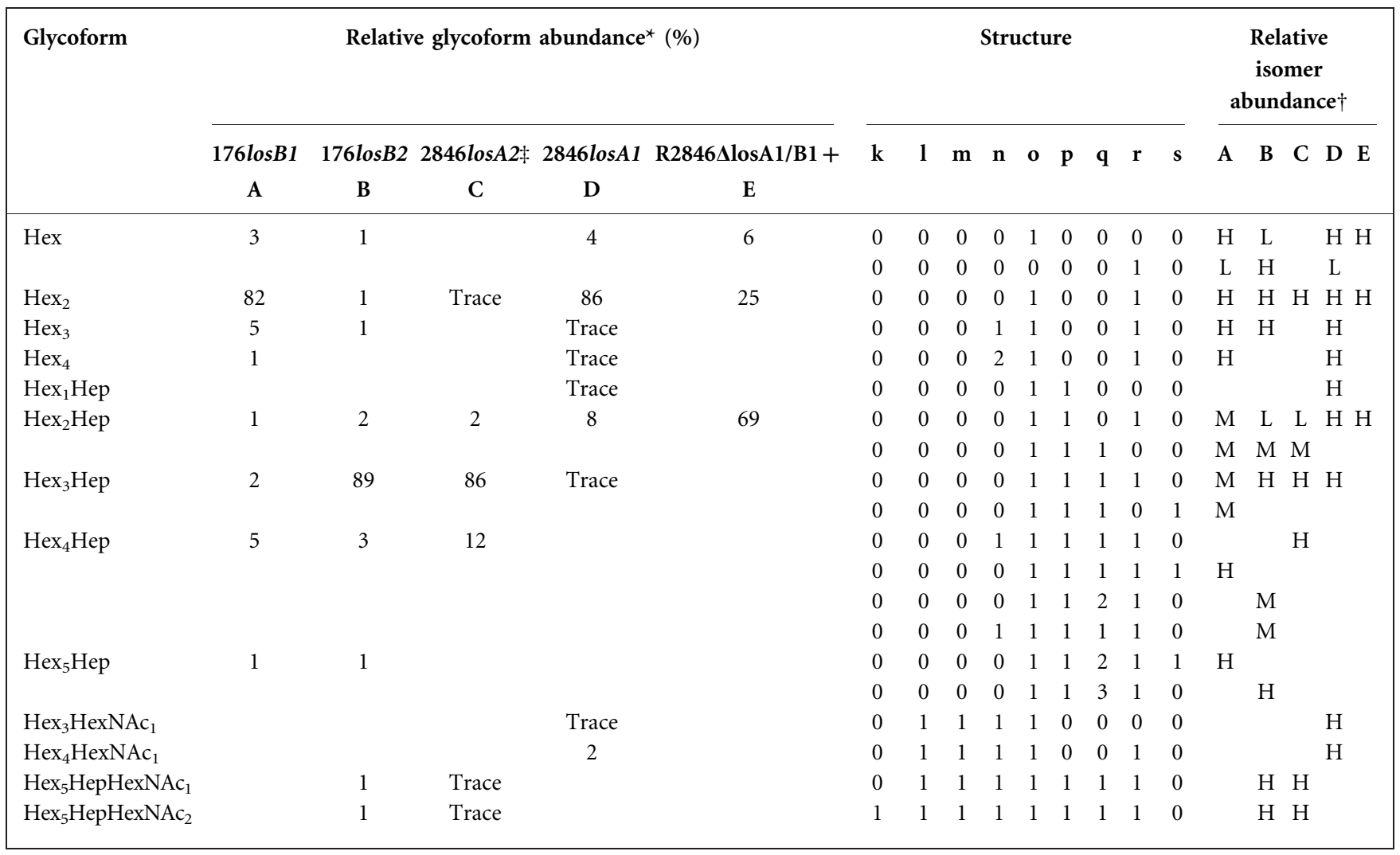

${ }^{\star}$ Relative abundance (percentage for each glycoform calculated from the detected molecular ions in the $\mathrm{MS}^{1}$ spectrum).

$\dagger$ Relative abundance for structural isomers of each glycoform calculated from the intensity of the product ions in the $\mathrm{MS}^{2}$ spectrum: $\mathrm{H}$ (high, $>80 \%$ ), M (medium, 80-30\%), L (low, 30-2\%).

¥Data virtually identical to those for R2846 wild-type and R2846losB2 (Lundström et al., 2008).

lic3B gene, encoding an LPS-specific sialyltransferase, is variably present amongst NTHi strains (Fox et al., 2006), and this is separated by a further gene from the chromosomal location where the $h m g$ locus (between HI0865 and HIO875 in the strain Rd genome sequence), encoding the incorporation of a four-sugar unit into the LPS, is present in about $60 \%$ of NTHi strains (Hood et al., 2004b). Both lic3B and the $h m g$ locus can enhance LPS sialylation, a crucial factor in the pathogenesis of $\mathrm{OM}$ in an experimental model of NTHi infection (Bouchet et al., 2003). The los $A 2 / \operatorname{los} B 2$, lic $3 B$ and $h m g$ loci were distributed such that any combination of up to two of the three regions was found in a given strain background, but no strain contained all three (data not shown). The reason why the $\operatorname{los} A / \operatorname{los} B$ genes are located in regions of the genome with variable insertion of genes is not clear. A 


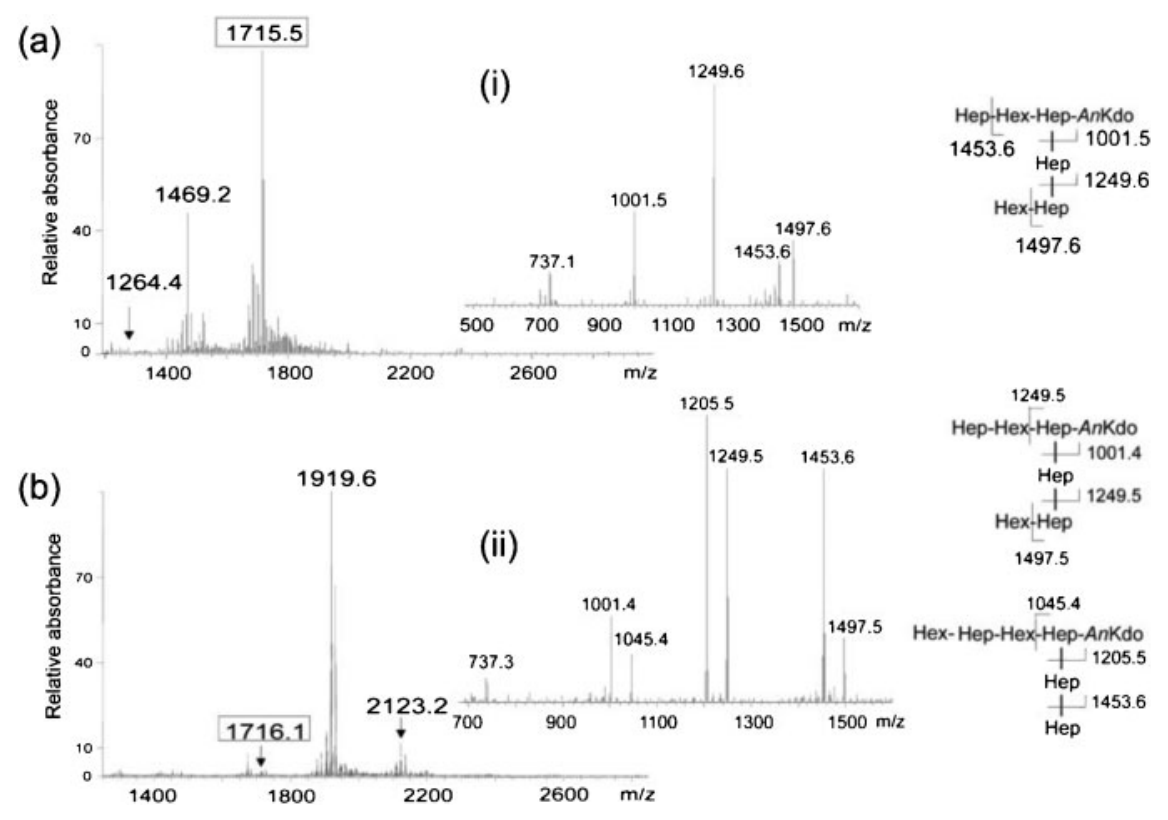

Fig. 4. LC-ESI-MS full-scan spectra of the derivatized LPS (permethylated OS) from R2846 mutant strains. (a) R2846 $\Delta$ losA1/ $\mathrm{B} 1+$, (b) R2846/osA2. The MS/MS spectra of the boxed ions and the corresponding glycoform structures are presented in (i) and (ii). The spectrum for R2846/osA2 in (b) is virtually identical to spectra for the R2486 parent and R2486/osB2 strains described previously (Lundström et al., 2008).

syntenic series of genes highly homologous $(>98 \%)$ to the losA2/losB2 island is present in P. multocida, consistent with a recent exchange of this region of DNA between genera.

Based upon structural analysis of LPS from the isogenic mutants in the strain 176 and R2846 backgrounds, losB1 encodes a DD-heptosyltransferase and losB2 an LD-heptosyltransferase. Both proteins are active in these strains, as a losB1 mutation switches incorporation from the normal DD-Hep to an LD-Hep, the former being incorporated exclusively in the wild-type (Lundström et al., 2008). When considering the distribution of los genes across NTHi, each strain in which HepIV is the LD-Hep enantiomer contains the $\operatorname{los} B 2$ gene, and with the exception of isolates 1158 and 1159 (DD-Hep), all strains expressing DD-Hep as HepIV contain the losB1 gene. DNA sequence analysis of losB2 from strain NTHi 1158 revealed a sequence highly homologous to losB2 from strains R2846 and 1207, differing uniquely at only two amino acids (data not shown). However, comparison of these sequence polymorphisms with the amino acid sequences of heptosyltransferases from other species (http://www.cazy.org) where the specificity for DD- or LD-Hep addition is known revealed that these changes might direct 1158 LosB2 function in a manner closer to that of LosB1 in other NTHi strains. One of the amino acids is located in the putative active site of the protein, and work is under way to confirm that these sequence polymorphisms direct the specificity of the heptose addition. In $H$. ducreyi, the $\operatorname{los} B$ homologue, lbgB, encodes a DD-heptosyltransferase required to incorporate a heptose equivalent to HepIV in $H$. influenzae, and it and the adjacent losA homologue, $\operatorname{lbg} A$, are flanked by genes encoding L31 ribososmal protein and exonuclease III (Post et al., 2007). This organization is similar to that of the $\operatorname{los} B 2$ gene in NTHi, but $\operatorname{LbgB}$ has a function similar to that of LosB1. The juxtaposition of the $\operatorname{los} A$ and $\operatorname{los} B$ genes makes it unsurprising that mutation of $\operatorname{los} A$ has an apparent polar effect on $\operatorname{los} B$ expression, resulting in an LPS phenotype in which no HepIV is incorporated. Through complementation of losB1 function in a R2846losA1 mutant strain we showed that HepIV was now included in the LPS but with no further OS elongation. This is consistent with LosA1 being a glucosyltransferase required to add the next hexose onto HepIV. By analogy and based on sequence differences compared with LosA1, we conclude that LosA2 acts as a galactosyltransferase for HepIV substitution, in the respective NTHi strains.

In strain R2846, the los $A 2$ and hgt 1 genes are truncated due to frameshifts and are likely non-functional. In an earlier study of losAl in NTHi, tandem copies of the octanucleotide $5^{\prime}$-CGAGCATA-3' controlled variable expression of the gene and the serum-resistant phenotype of the bacteria (Erwin et al., 2006b). This repeat tract is not present in $\operatorname{los} A 2$. When $\operatorname{los} A 1$ was inactivated in strain R2846 in the study of Erwin et al. (2006b), a truncation of the LPS was found, similar to the results in our study, but no corresponding change in LPS phenotype was observed when the number of octanucleotide repeats changed from one permissive for translation of the gene to one not, and 
vice versa. This discrepancy likely reflects the co-dependence of $\operatorname{los} A 1$ and $\operatorname{los} B 1$ transcriptional (but not translational) expression indicated in our study.

$H$. influenzae has several strategies to enhance LPS structural variation within and between strains. These include phase-variable expression of LPS biosynthesis genes, sequence polymorphisms directing alternative LPS phenotypes, and differences in the number and nature of LPS genes between strains. This list can now be refined to include mutually exclusive LPS gene sets found at the same genomic location. The alternative gene organizations at the infA/ksgA site in the genome direct either OS elongation from the middle heptose (HepII) (lic2B/lic2C) of the LPS inner core or inclusion and substitution of HepIV in OS extensions from HepI (losA1/losB1), LPS patterns that must be mutually exclusive and that can influence the diseasecausing properties of the molecule (Erwin et al., 2005; Hood et al., 2004a).

In conclusion, we have identified two sets of genes that add and substitute a fourth heptose in OS extensions in some NTHi LPS. These genes underlie a further example of the extreme genetic and phenotypic diversity of LPS between strains that exists to increase the fitness of the bacteria during interactions with the host.

\section{ACKNOWLEDGEMENTS}

M.E.D., K.M. and D.W.H. were supported by grants from the Medical Research Council, UK.

\section{REFERENCES}

Anderson, P., Johnston, R. B., Jr \& Smith, D. H. (1972). Human serum activities against Hemophilus influenzae, type b. J Clin Invest 51, 31-38.

Bouchet, V., Hood, D. W., Li, J., Brisson, J. R., Randle, G. A., Martin, A., Li, Z., Goldstein, R., Schweda, E. K. \& other authors (2003). Hostderived sialic acid is incorporated into Haemophilus influenzae lipopolysaccharide and is a major virulence factor in experimental otitis media. Proc Natl Acad Sci U S A 100, 8898-8903.

Cody, A. J., Field, D., Feil, E. J., Stringer, S., Deadman, M. E., Tsolaki, A. G., Gratz, B., Bouchet, V., Goldstein, R. \& other authors (2003). High rates of recombination in otitis media isolates of non-typeable Haemophilus influenzae. Infect Genet Evol 3, 57-66.

Danner, D. B. \& Pifer, M. L. (1982). Plasmid cloning vectors resistant to ampicillin and tetracycline which can replicate in both $E$. coli and Haemophilus cells. Gene 18, 101-105.

Deadman, M. E., Lundström, S. L., Schweda, E. K., Moxon, E. R. \& Hood, D. W. (2006). Specific amino acids of the glycosyltransferase LpsA direct the addition of glucose or galactose to the terminal inner core heptose of Haemophilus influenzae lipopolysaccharide via alternative linkages. J Biol Chem 281, 29455-29467.

Deadman, M. E., Hermant, P., Engskog, M., Makepeace, K., Moxon, E. R., Schweda, E. K. \& Hood, D. W. (2009). Lex2B, a phase-variable glycosyltransferase, adds either a glucose or a galactose to Haemophilus influenzae lipopolysaccharide. Infect Immun 77, 2376-2384.

Erwin, A. L., Nelson, K. L., Mhlanga-Mutangadura, T., Bonthuis, P. J., Geelhood, J. L., Morlin, G., Unrath, W. C., Campos, J., Crook, D. W. \& other authors (2005). Characterization of genetic and phenotypic diversity of invasive nontypeable Haemophilus influenzae. Infect Immun 73, 5853-5863.

Erwin, A. L., Allen, S., Ho, D. K., Bonthuis, P. J., Jarisch, J., Nelson, K. L., Tsao, D. L., Unrath, W. C., Watson, M. E., Jr \& other authors (2006a). Role of $\operatorname{lgtC}$ in resistance of nontypeable Haemophilus influenzae strain R2866 to human serum. Infect Immun 74, 62266235.

Erwin, A. L., Bonthuis, P. J., Geelhood, J. L., Nelson, K. L., McCrea, K. W., Gilsdorf, J. R. \& Smith, A. L. (2006b). Heterogeneity in tandem octanucleotides within Haemophilus influenzae lipopolysaccharide biosynthetic gene losA affects serum resistance. Infect Immun 74, 3408-3414.

Fleischmann, R. D., Adams, M. D., White, O., Clayton, R. A., Kirkness, E. F., Kerlavage, A. R., Bult, C. J., Tomb, J. F., Dougherty, B. A. \& other authors (1995). Whole-genome random sequencing and assembly of Haemophilus influenzae Rd. Science 269, 496-512.

Fox, K. L., Cox, A. D., Gilbert, M., Wakarchuk, W. W., Li, J., Makepeace, K., Richards, J. C., Moxon, E. R. \& Hood, D. W. (2006). Identification of a bifunctional lipopolysaccharide sialyltransferase in Haemophilus influenzae: incorporation of disialic acid. J Biol Chem 281, 4002440032.

Fox, K. L., Li, J., Schweda, E. K., Vitiazeva, V., Makepeace, K., Jennings, M. P., Moxon, E. R. \& Hood, D. W. (2008). Duplicate copies of licl direct the addition of multiple phosphocholine residues in the lipopolysaccharide of Haemophilus influenzae. Infect Immun 76, 588600.

Gulin, S., Pupo, E., Schweda, E. K. \& Hardy, E. (2003). Linking mass spectrometry and slab-polyacrylamide gel electrophoresis by passive elution of lipopolysaccharides from reverse-stained gels: analysis of gel-purified lipopolysaccharides from Haemophilus influenzae strain Rd. Anal Chem 75, 4918-4924.

Harrison, A., Dyer, D. W., Gillaspy, A., Ray, W. C., Mungur, R., Carson, M. B., Zhong, H., Gipson, J., Gipson, M. \& other authors (2005). Genomic sequence of an otitis media isolate of nontypeable Haemophilus influenzae: comparative study with $H$. influenzae serotype d, strain KW20. J Bacteriol 187, 4627-4636.

Herriott, R. M., Meyer, E. M. \& Vogt, M. (1970). Defined nongrowth media for stage II development of competence in Haemophilus influenzae. J Bacteriol 101, 517-524.

High, N. J., Jennings, M. P. \& Moxon, E. R. (1996). Tandem repeats of the tetramer $5^{\prime}$-CAAT- $3^{\prime}$ present in lic $2 A$ are required for phase variation but not lipopolysaccharide biosynthesis in Haemophilus influenzae. Mol Microbiol 20, 165-174.

Hood, D. W., Deadman, M. E., Allen, T., Masoud, H., Martin, A., Brisson, J. R., Fleischmann, R., Venter, J. C., Richards, J. C. \& Moxon, E. R. (1996a). Use of the complete genome sequence information of Haemophilus influenzae strain Rd to investigate lipopolysaccharide biosynthesis. Mol Microbiol 22, 951-965.

Hood, D. W., Deadman, M. E., Jennings, M. P., Bisercic, M., Fleischmann, R. D., Venter, J. C. \& Moxon, E. R. (1996b). DNA repeats identify novel virulence genes in Haemophilus influenzae. Proc Natl Acad Sci U S A 93, 11121-11125.

Hood, D. W., Makepeace, K., Deadman, M. E., Rest, R. F., Thibault, P., Martin, A., Richards, J. C. \& Moxon, E. R. (1999). Sialic acid in the lipopolysaccharide of Haemophilus influenzae: strain distribution, influence on serum resistance and structural characterization. Mol Microbiol 33, 679-692.

Hood, D. W., Cox, A. D., Wakarchuk, W. W., Schur, M., Schweda, E. K., Walsh, S. L., Deadman, M. E., Martin, A., Moxon, E. R. \& Richards, J. C. (2001). Genetic basis for expression of the major globotetraosecontaining lipopolysaccharide from $H$. influenzae strain Rd (RM118). Glycobiology 11, 957-967. 
Hood, D. W., Deadman, M. E., Cox, A. D., Makepeace, K., Martin, A., Richards, J. C. \& Moxon, E. R. (2004a). Three genes, lgtF, lic $2 C$ and $l p s A$, have a primary role in determining the pattern of oligosaccharide extension from the inner core of Haemophilus influenzae LPS. Microbiology 150, 2089-2097.

Hood, D. W., Randle, G., Cox, A. D., Makepeace, K., Li, J., Schweda, E. K., Richards, J. C. \& Moxon, E. R. (2004b). Biosynthesis of cryptic lipopolysaccharide glycoforms in Haemophilus influenzae involves a mechanism similar to that required for O-antigen synthesis. J Bacteriol 186, 7429-7439.

Houliston, R. S., Koga, M., Li, J., Jarrell, H. C., Richards, J. C., Vitiazeva, V., Schweda, E. K., Yuki, N. \& Gilbert, M. (2007). A Haemophilus influenzae strain associated with Fisher syndrome expresses a novel disialylated ganglioside mimic. Biochemistry 46, 8164-8171.

Lundström, S. L., Li, J., Deadman, M. E., Hood, D. W., Moxon, E. R. \& Schweda, E. K. (2008). Structural analysis of the lipopolysaccharide from nontypeable Haemophilus influenzae strain R2846. Biochemistry 47, 6025-6038.

Månsson, M., Hood, D. W., Moxon, E. R. \& Schweda, E. K. (2003a). Structural characterization of a novel branching pattern in the lipopolysaccharide from nontypeable Haemophilus influenzae. Eur J Biochem 270, 2979-2991.

Månsson, M., Hood, D. W., Moxon, E. R. \& Schweda, E. K. (2003b). Structural diversity in lipopolysaccharide expression in nontypeable Haemophilus influenzae. Identification of L-glycerol-D-manno-heptose in the outer-core region in three clinical isolates. Eur J Biochem 270, 610-624.

Patrick, C. C., Kimura, A., Jackson, M. A., Hermanstorfer, L., Hood, A., McCracken, G. H., Jr \& Hansen, E. J. (1987). Antigenic characterization of the oligosaccharide portion of the lipooligosaccharide of nontypable Haemophilus influenzae. Infect Immun 55, 2902-2911.

Pettigrew, M. M., Foxman, B., Marrs, C. F. \& Gilsdorf, J. R. (2002). Identification of the lipooligosaccharide biosynthesis gene lic $2 B$ as a putative virulence factor in strains of nontypeable Haemophilus influenzae that cause otitis media. Infect Immun 70, 3551-3556.
Phillips, N. J., Apicella, M. A., Griffiss, J. M. \& Gibson, B. W. (1992). Structural characterization of the cell surface lipooligosaccharides from a nontypable strain of Haemophilus influenzae. Biochemistry 31, 4515-4526.

Post, D. M., Munson, R. S., Jr, Baker, B., Zhong, H., Bozue, J. A. \& Gibson, B. W. (2007). Identification of genes involved in the expression of atypical lipooligosaccharide structures from a second class of Haemophilus ducreyi. Infect Immun 75, 113-121.

Preston, A., Maskell, D., Johnson, A. \& Moxon, E. R. (1996). Altered lipopolysaccharide characteristic of the I69 phenotype in Haemophilus influenzae results from mutations in a novel gene, isn. J Bacteriol 178, 396-402.

Sambrook, J., Fritsch, E. F. \& Maniatis, T. (1989). Molecular Cloning: a Laboratory Manual, 2nd edn. Cold Spring Harbor, NY: Cold Spring Harbor Laboratory.

Schweda, E. K., Richards, J. C., Hood, D. W. \& Moxon, E. R. (2007). Expression and structural diversity of the lipopolysaccharide of Haemophilus influenzae: implication in virulence. Int J Med Microbiol 297, 297-306.

Schweda, E. K., Twelkmeyer, B. \& Li, J. (2008). Profiling structural elements of short-chain lipopolysaccharide of non-typeable Haemophilus influenzae. Innate Immun 14, 199-211.

Tullius, M. V., Phillips, N. J., Scheffler, N. K., Samuels, N. M., Munson Jr, R. S., Jr, Hansen, E. J., Stevens-Riley, M., Campagnari, A. A. \& Gibson, B. W. (2002). The lbgAB gene cluster of Haemophilus ducreyi encodes a $\beta$-1,4-galactosyltransferase and an $\alpha$-1,6-DD-heptosyltransferase involved in lipooligosaccharide biosynthesis. Infect Immun 70, 2853-2861.

Weiser, J. N., Love, J. M. \& Moxon, E. R. (1989). The molecular mechanism of phase variation of $H$. influenzae lipopolysaccharide. Cell 59, 657-665.

Zamze, S. E. \& Moxon, E. R. (1987). Composition of the lipopolysaccharide from different capsular serotype strains of Haemophilus influenzae. J Gen Microbiol 133, 1443-1451.

Edited by: M. Kilian 